a Conference convenod by the Royal Society on 16 September, 1965. Pp. 14. London: The Royal Society, 1965). Prof. H. W. Thompson was in the chair, and in the procoed. ings sixty-two people took part. Tho chiof conclusions and recommendations which emerged were that a very considerable increase in in-service training for teachers of science and mathematics was urgent. The Department of Education and Science together with Local Education Authorities were urged to provide the necessary financial assistance; in-service training and the development of the science curriculum should go hand in hand; and further links should be established between tho learned societies and professional institutes concerned and school teachers of science, to strengthen a sense of community. Those organizations already active in the field should be encouraged to continue, with co-ordination when necessary, perhaps through the Schools Council-in this respect, what was already being done by the Schools Council met with general approval. The recommendations of the Joint Mathematical Council were endorsed. Local Education Authorities, it was felt, should act generously in supporting teachers who wished to attend courses; and the Royal Society should bring the report of the meeting to the attention of a wide range of public bodies, universities and other interested groups. Hesitation about these conclusions came mainly from K. S. Tetlow, representing the teachers' point of view. His enquiries had shown that no teachers were interested in courses of one term's duration or more; there was no enthusiasm for courses held during the holidays; and the pupils would suffer if courses were held during term time. 'There was, however, a strong desire for more information about modern advances in science, as well as for courses of one or a few days' duration, held at strategic times during the school year.

\section{Registrar General's Quarterly Return}

The Registrar General's Quarterly Return for the June quarter of 1965 shows that births in the first two quarters of 1965 were fractionally lower than in the corresponding quartors of the previous year $(439,000$ as against 449,000$)$ (General Register Office. The Registrar General's Quarterly Return for England and Wales-Births, Deaths and Mar. riages; Infectious Diseases; Weather; Population Estimates, Quarter ended 30th June, 1965. Pp. 40. London: H.M.S.O., 1965. 2s, 6d.). The seasonally adjusted birthrato has also fallen slightly. This is the first time during the past ten years that the figures have failed to show an increase, but it is difficult to draw any conclusion from this short period. The infant mortality rates continue to decline, and have fallen by 25 per cent during the past ten years. Marriages tend to be stable in number. The first provisional analysis of death in 1964 by cause, age and sox appears in the Return: deaths from lung cancer were 3.5 per cent up on the 1963 figuros among mon and nearly 6 per cent up among women; the increase in deaths due to motor vehicle accidents was nearly 15 per cent among both sexes. Nearly 45 per cent of the deaths of males aged 15-24 were attributable to this cause. The expectation of life at birth in 1962-64 was 68.1 years for men and 74.2 for womon.

\section{Fuels for the Future}

"MAN's use of energy has progressed from wood and dung to coal and oil, is now taking a large contribution from gas and moving towards uranium, piutonium, and ultimately sea-wator." This challonging statemont, appears towards the end of an entertaining and prophetio article by Keith Richardson entitled "Fuels for tho Future" (Catalyst, 15; Autumn 1965. London: Shell Chemical Co., Ltd., Plastics and Rubbers and Industrial Chemicals Divisions). Mr. Richardson surveys the present highly competitive fields of coal, oil, electricity and gas; and the future impact of nuclear energy. Of the coal industry, he says that the main trouble is its great in- flexibility. The over-riding question is, what is the future of the coal industry in our economic scheme of things? At present, it produces 66 million tons a year from lossmaking pits, mainly in Scotland, Wales and the NorthEast. Arguments in favour of keeping a strategic reserve of coal capacity - pits that can be opened if ever neededare attractive, but impracticable; onco a coal mine is closed it is closed for ever, because of rock-pressure and water flooding; if we are to be able to call on 200 million tons of home-produced coal in the futuro, that same amount must be bought now to keep the pits in being. Before coal is ever likely "to get into balance", uneconomic pits must be abandoned. "The tragedy is that business which could profitably be won by Midlands coal at $£ 2$ a ton is lost to oil because the price structure is all wrong." It is the oil industry that has damaged coal, but it has also spurred it to greater efficiency. Mr. Richardson considers that the oil supply situation looks as though it will become tougher between 10 and 30 years from now, because costs of exploration and of extraction will rise; oil-bearing countries may grow reluetant to let so much of their resources be shipped to Britain as they now do; this, it is argued, is why the present North Sea explorations are so tremendously important. In the latter context, gas is now better envisaged as an offshoot of the oil industry, bccauso the British Gas Council can make its own gas just as cheaply from oil as from other sources; ". . as surely as oil has won fuel business from coal, in time it will lose it back to electricity". But the golden future thus predicted for electricity depends neither on coal nor on oil (including gas), but on atomic power. The advanced gas-cooled reactor now offers the cheapest means of generating electricity. By the 1980's fast breeder reactors should produce more fuel than they use. Two other intriguing possibilities for future fuels are brienly discussed in this article: one is the prospect of the fuel cell gradually replacing tho petrol and diesel engine; the other is thermonuclear fusion. If the latter is a practicable source, it means power from sea-water "in virtually unlimited quantities". Finally, there is that devastating machine called the 'Thetatron', ". . . which in six-millionths of a second can develop 12 million amps of current, and this has achieved momentary bursts of 10 million degrees". As Mr. Richardson naively says, at least it points the way. This is an extremely able essay into the complex problems of fuels for the future.

\section{Balancing Capacity and Sales}

Achieving Balance between Capacity and Sales, a booklet containing papers given at a conference on this theme at Birmingham during May 1965, is now available (Pp. 31. London: British Productivity Council, 1965). The conference was organized by the British Productivity Council, in co-operation with the British Institute of Management, the Centre for Inter-firm Comparison and the Birmingham and Coventry Productivity Associations. The introductory paper, by $\mathrm{H}$. Ingham, dircctor of the Centre for Interfirm Comparison, stated that there are a few frequently occurring and typical patterns of co-ordination between sales and capacity, each of which can be described as a basic marketing objective with resultant typical opportunities and risks. Companies of a similar type, although making different products, face broadly similar problems of balance, so that a firm can improve its methods of co-ordination by comparing them with those of other firms of its typo. Tho co-ordination outlined in the type descriptions given can be used as 'blueprints'. Ingham also discussed the influenees of co-ordination practices on profitability. Three case studies were also presented to show typical major patterns of co-ordination: the first by $\mathrm{H}$. A. Hollingsworth, chief production controller of Wilmot Breeden, Ltd.; the second by J. W. Fewless, director of the Heath Street Division of G.K.N. Screws and Fasteners, Ltd.; and the third by I. A. Williams. 